University of Nebraska - Lincoln

DigitalCommons@University of Nebraska - Lincoln

Faculty Publications, Classics and Religious

Studies Department

January 1993

\title{
THREE DEUTERONOMY MANUSCRIPTS FROM CAVE 4, QUMRAN
}

Sidnie White Crawford

University of Nebraska-Lincoln, scrawford1@unl.edu

Follow this and additional works at: https://digitalcommons.unl.edu/classicsfacpub

Part of the Classics Commons

Crawford, Sidnie White, "THREE DEUTERONOMY MANUSCRIPTS FROM CAVE 4, QUMRAN" (1993). Faculty Publications, Classics and Religious Studies Department. 14.

https://digitalcommons.unl.edu/classicsfacpub/14

This Article is brought to you for free and open access by the Classics and Religious Studies at DigitalCommons@University of Nebraska - Lincoln. It has been accepted for inclusion in Faculty Publications, Classics and Religious Studies Department by an authorized administrator of DigitalCommons@University of Nebraska - Lincoln. 
JBL 112/1 (1993) 23-42

\section{THREE DEUTERONOMY MANUSCRIPTS FROM CAVE 4, QUMRAN}

SIDNIE ANN WHITE

Albright College, Reading, PA 19612-5234

The purpose of this article is to present three hitherto unpublished manuscripts (part of the twenty-one Deuteronomy manuscripts from Cave 4, Qumran): 4QDta ${ }^{\mathrm{a}}$ 4QDtd, and 4QDtg. These three manuscripts are placed together in this article because each has a particular feature of interest: $4 \mathrm{QDt}^{\mathrm{a}}$ is the oldest of the Cave 4 Deuteronomy manuscripts; $4 \mathrm{QDt} \mathrm{t}^{\mathrm{d}}$ contains a very defective orthography; and $4 \mathrm{QD}$ tg presents a text identical to that of the Masoretic text. ${ }^{2}$ In the body of the article, each manuscript is presented separately, beginning with a description of the physical characteristics of each manuscript. This description is followed by a complete transcription (with reconstruction ${ }^{3}$ ), with a set of notes on the readings and a textual apparatus. ${ }^{4}$ Photographs of each manuscript are included with the transcription.

\section{QDta}

4QDta the oldest Deuteronomy manuscript from Cave 4, consists of one large fragment which is a yellowish-brown color, with darker stains in spots. The leather is of average thickness. The height of the fragment is 10 centimeters, and its width at the broadest points is 13.9 centimeters. The surface of the leather was originally smooth and well prepared; now some wrinkling and shrinkage have occurred, leaving some cracks on the surface. The fragment has one sewn edge on the right-hand side. There are no visible dry lines

\footnotetext{
${ }^{1}$ The sigla are as follows: $4=$ Cave 4; $Q=$ Qumran; $D t=$ Deuteronomy; $x=$ the letter assigned to each manuscript. These manuscripts are part of the lot of seven manuscripts assigned to me for publication by Frank Moore Cross. For the preliminary edition of these manuscripts, see my 1988 Harvard University dissertation "Seven Deuteronomy Manuscripts from Cave IV, Qumran: 4QDt ${ }^{\mathrm{a}}, 4 \mathrm{QDt}^{\mathrm{c}}, 4 \mathrm{QDt}^{\mathrm{d}}, 4 \mathrm{QDt}^{\mathrm{f}}, 4 \mathrm{QDt}$, 4QDt $\mathrm{i}$, and 4QDt"."

${ }^{2}$ See Sidnie Ann White, "Special Features of Four Biblical Manuscripts from Cave IV, Qumran: 4QDt ${ }^{\mathrm{a}}, 4 \mathrm{QDt} \mathrm{t}^{\mathrm{c}}, 4 \mathrm{QDt} \mathrm{t}^{\mathrm{d}}$, and 4QDtg," RevQ 15 (1991) 157-67.

${ }^{3}$ The reconstruction follows the MT, unless otherwise noted.

${ }^{4}$ The textual apparatus includes readings from the other major witnesses to Deuteronomy outside Qumran. It does not contain cross-reference to other Qumran Deuteronomy manuscripts. These cross-references will appear in the editio princeps of all the Cave 4 Deuteronomy manuscripts forthcoming in Discoveries in the Judaean Desert XI (Oxford University Press).
} 
on the fragment, but the writing is remarkably consistent in following a hypothetical horizontal dry line. The average space from line to line is 9 millimeters. The width of the margin to the sewn edge is 12.5 millimeters. The column width in letter spaces is 51-61 spaces, and in centimeters 12.75 (reconstructed).

Empty spaces are present in this manuscript which agree with the placement of setûmôt in MT (indicated by VACAT in the transliteration). These occur before 24:1; 24:5; 24:7 (the space here is very small); and possibly after 24:8 (the manuscript breaks off at this point). An empty space is not present before 24:6 ( $\square$ in MT). There are no empty spaces on this manuscript that do not agree with setûmôt in MT.

The manuscript preserves portions of Deut 23:26-24:8.

Paleography establishes this hand in the transition period from the archaic to the formal Hasmonean hand, ca. $175-150$ всE. ${ }^{5}$ The letter size is variable: for example, the 'alep can be quite small, while the taw is still fairly large. In later Hasmonean scripts, letter size becomes standardized, e.g., 4QDtc, 4QSam ${ }^{a}{ }^{6}$ Thick and thin pen strokes are still in use, e.g., yod and mem. The script is slightly later than that of $4 Q^{2} a^{b}$ and 4 QJera , but earlier than that of 4 QSam ${ }^{\mathrm{a}}$ (for example, the bending to the left of the leg on medial sadê in $4 Q^{2} t^{a}$ does not occur in either 4 QSamb or 4 QJera).

The orthography of $4 \mathrm{QDta}$ is occasionally more archaic than, but usually agrees with, the Masoretic tradition, with לא, and the short pronominal forms (e.g., ת-, 7-, and הוא). Yod is used as a mater lectionis only for ${ }^{* \overline{1}}$ and *ay > $\hat{e}$. Waw is used regularly for * $\overline{\mathrm{u}}$, *aw $>\hat{o}$, and the suffix of the third singular, and it is occasionally used to mark ${ }^{*} \bar{a}>\bar{o}$ when accented (e.g., להיות), but not for any shorter $u$ vowel (e.g., יעבר), כל כhe one instance where the orthography of the Samaritan Pentateuch differs from the extant text of 4Q and that of MT, it uses double matres lectionis, e.g., 4Q, MT נקיא SP (this orthography is found in MT only in Jonah 1:14).

The following is a list of merely orthographical variants found in this manuscript:

24:3 (line 4): כריתת [ כרתת MT SP. The 4Q form is archaic; it is not attested elsewhere. In this manuscript we would expect a yod written for $*_{\mathrm{i}}$. We do not expect a mater lectionis for $*_{\mathrm{u}}$.

24:4 (line 5): הראישון SP. 4Q has not marked *ā > ō.

$4 \mathrm{Q}$ preserves a morphological variant at line 8 :

24:5 ולא יעכר עליו לכל [ ולא יעכר עליו כל] MT SP Tar: $w l^{\prime} n^{\prime} z l l k l$ Syr.

\footnotetext{
${ }^{5}$ Frank Moore Cross, "The Development of the Jewish Scripts," in The Bible and the Ancient Near East: Essays in Honor of William Foxwell Albright (Anchor Books A431; Garden City, NY: Doubleday, 1965) 166.

${ }^{6}$ Ibid., 167.
} 
$4 Q$ preserves a unique variant. $ל$ in the other forms of the text is functioning as the direct object marker; this is a late influence on Hebrew from Aramaic (G, which is in the dative case, is ambiguous). Cf. Syr, Tar, where $ל$ is expected.

$4 \mathrm{QDt}^{\mathrm{a}}$ is difficult to place in a textual family, because of its small size, which limits the number of variants preserved. Nor does the text that is preserved on the fragment contain any obvious errors, which makes the question of textual affiliation unresolvable.

Deut 23:26-24:8

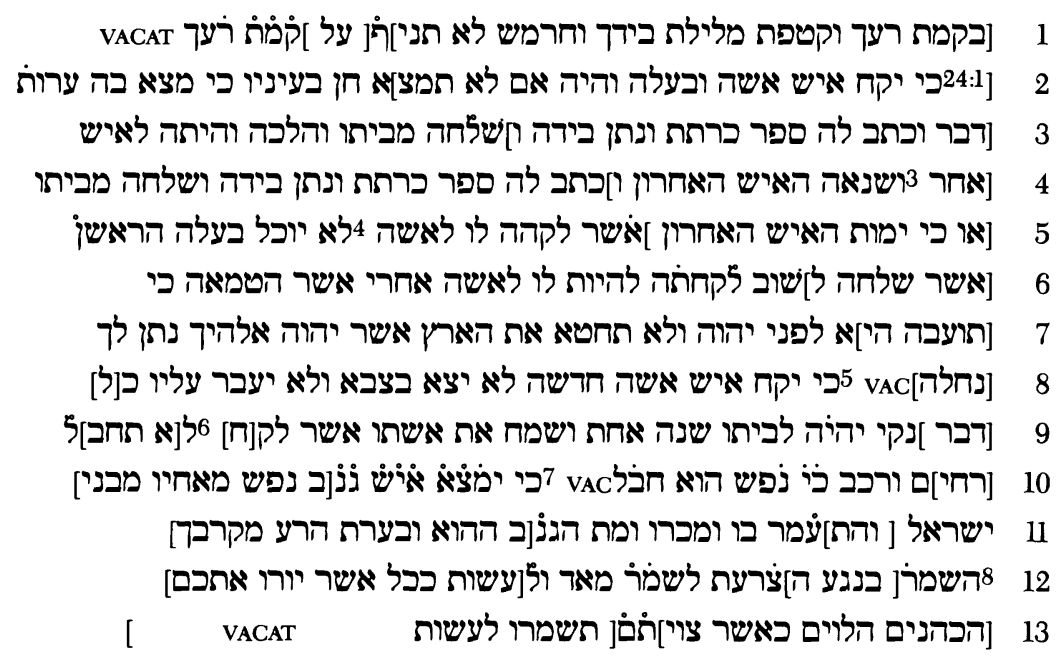

Notes on Readings

line Deut

5 ה הראשי A damaged letter is extant to the left of šin. It appears to be the curve of final nun. It could conceivably be interpreted as a $w a w$, but given the orthographical practice of this manuscript, it should be final nun.

13 24:8 צוי[ת 13 The head of final mem is extant on the leather. To its right traces of ink are discernible. Based on our reconstruction of the text, according to the number of letter spaces available, we have restored taw.

Textual Notes

line Deut

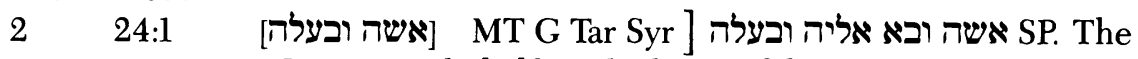
SP text is excluded by calculation of the space at our disposal. 

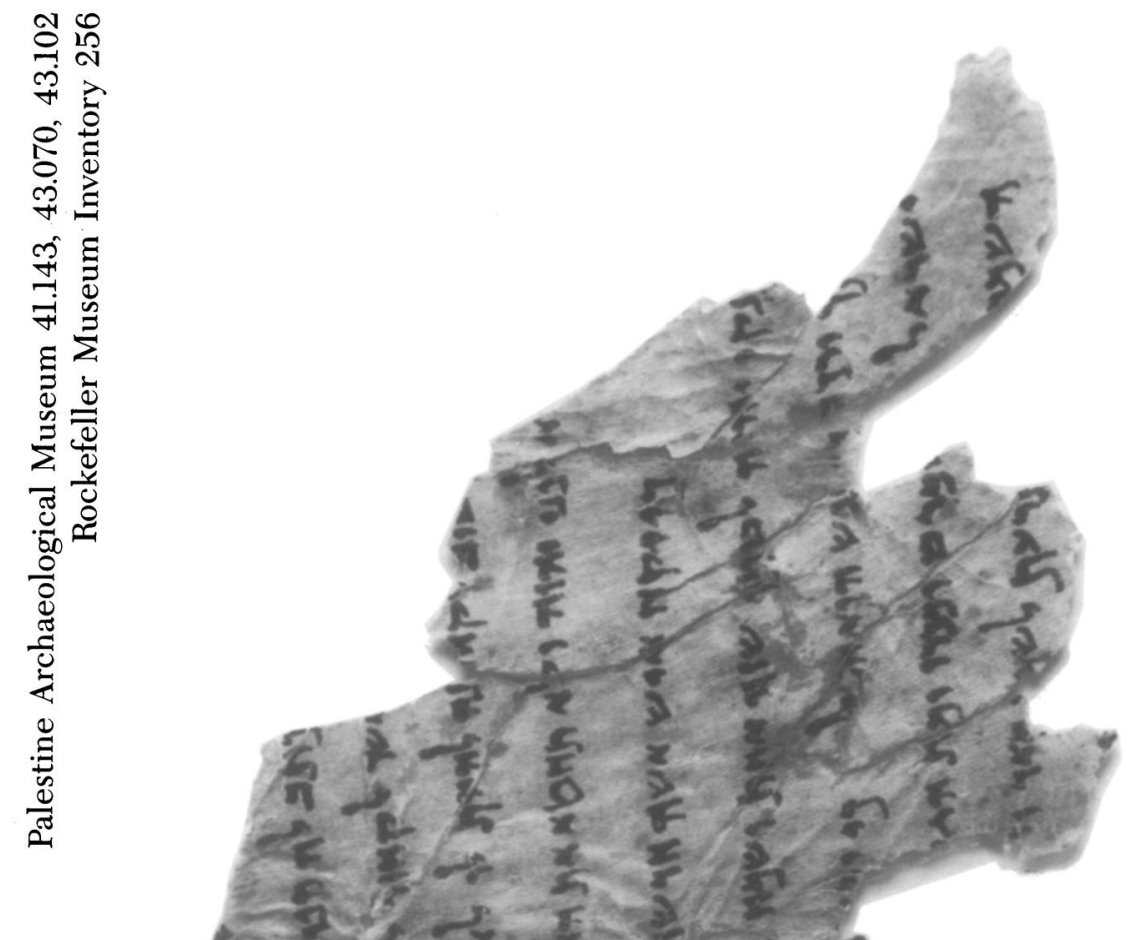
The verse must begin at the beginning of line 2 , because we have an empty space at the end of line 1 , the end of chap. 23. We have space at the beginning of line 2 , before the extant text, for approximately 35 letter spaces. If we restored the text of SP, the letter space count would be 44 , giving a line that would be much too crowded. The text of SP is expansionistic, affected by the text of 22:13.

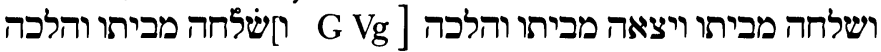
MT SP Tar: wnšryh wtpwq mn byth w'n t'zl Syr. 4Q, G, and Vg have the same shorter text (contra $B H S ; \alpha \pi \varepsilon p \times \varepsilon \sigma \theta \alpha_{l}={ }^{2}$ הל). Syr does not repeat מבית, although it does have the two verbs of MT. This may indicate that the longer text of MT et al. is conflate, with Syr showing only partial conflation. The text of $4 \mathrm{Q}, \mathrm{G}$, et al. then would be preferable. On the other hand, it could be argued that 4Q et al. have suffered from haplography and that the longer text of MT is preferable. Syr would then be showing partial correction back to the text of MT.

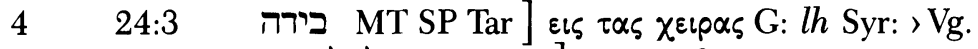

$524: 3 \quad$ לו לאשה ב MT SP G ] Syr: cf. Tar.

$624: 4 \quad$ לקחתה להיות לו לאשה GT SP Tar Vg ] לקחתה לו לאשה G: nsbyh Syr.

תחטיא [ תחטא MT Tar Syr: תחטיאו SP G.

$7 \quad 24: 4$

יהוה אלהיך G. G is an example of the unconscious assimilation to a conventional formula (or anticipation; see end of verse); יהוה אלהיך is found throughout Deuteronomy. The shorter text of $4 \mathrm{Q}, \mathrm{MT}$, et al. is preferable.

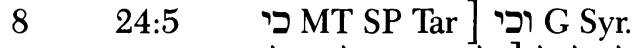

$824: 5$ ולא יעבר עליו לכל [ ולא יעבר עליו כלי] Syr. See above (p. 24).

יהיה MT SP G Tar ] 'l' $n h w$ ' Syr = sed vacabit Vg.

תחב] G Syr [ יחבל MT SP Tar. The 2nd masc. sing. form of the verb is correct in this negative commandment. We may assume that the 3rd masc. sing. verb in MT et al. is the result of reminiscence and anticipation of the surrounding verses. We would restore what we believe to be the preferable reading, although it is impossible positively to determine the reading of $4 \mathrm{Q}$.

10 ורכב MT SP G Tar ] cf. Syr.

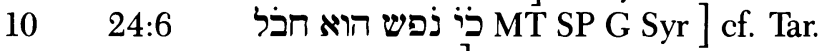

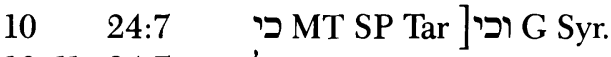

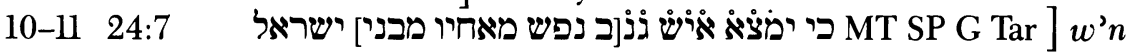
nštkh gbr' mn bny 'ysryl dngnwb npš' mn 'nnwhy mn bny 'ysryl Syr. 
11 ומפת MT SP G Tar ] mtqtllw ntqtl Syr.

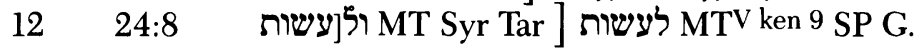

\section{$4 Q^{d} t^{d}$}

$4 \mathrm{QDt}$ is a yellowish-brown manuscript, stained gray in places, with some blackened portions. The leather is smooth and glossy. A certain amount of wrinkling and shrinkage has taken place, causing some damage to the surface. The leather is of average thickness. The left margin has a sewn edge. There are visible horizontal dry lines on the manuscript.

The manuscript consists of two partially damaged columns. The average inscribed column width is 10.8 centimeters, while the width in letter spaces for col. 1 is 59-68 spaces, and for col. 2, 53-63 spaces. The width of the left margin from the inscribed text to the edge of the fragment is 10 millimeters; the width of the margin between the columns is 12 millimeters (averaged). The average space from line to line is 8 millimeters. There are approximately 27 lines per column (reconstructed according to BHS). The height of the extant inscribed column, from the lowest point to the highest point, is 16.9 centimeters.

4QDtd contains an empty space at the end of chap. 3 (col. 2, line 20), which agrees with the placement of a $\Xi$ in MT. It does not, however, observe the empty spaces that the MT contains at 2:30; 3:17; and 3:22 (marked with D). The columns preserve portions of Deut 2:24-36 and 3:14-4:1.

The paleographical study of this manuscript places it in the middle Hasmonean period, ca. 100 вCE. The letters are of standard size and unornamented. The script is characterized by the use of ligatures for certain letters, particularly medial nun. Several features of the script are important for dating: the base stroke of bet is penned from right to left; dalet has a very deep-cornered head, typical of the Hasmonean form; tet is made in two strokes, with a slight bump formed by the juncture of the base and the right downstroke; yod is short, with a triangular head; medial kaf appears in two forms, with the late Hasmonean form of a straight, slightly slanted downstroke predominating; finally, the flaring tick common on the head of qof in earlier scripts has practically disappeared.

The orthography of $4 \mathrm{QDt} \mathrm{t}^{\mathrm{d}}$ is consistently more defective than the traditions of either MT or SP. The manuscript uses matres lectionis to indicate *aw > ô (e.g., עוד). However, this usage is not clear for the hiphil of verbs I yod (e.g., תס, col. 2, line 16). A mater lectionis is used to mark *ay > ê (e.g., בנריך, עיריך,

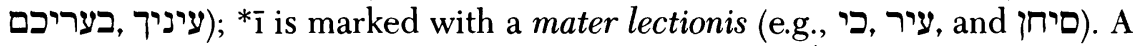

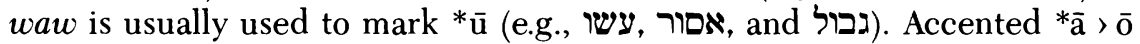
is sometimes indicated by a mater lectionis (e.g., חשבון, col. 1, line 3), but this usage is not consistent (accented $*_{\bar{a}}>\overline{0}$ is consistently not marked with waw in verbs III he, e.g., הראת, col. 2, line 10). Unaccented $* \bar{a}>\overline{0}$ is consistently not marked with waw (e.g., לא, all forms of אלהים, and all examples of the 
participle). A mater lectionis is not used to indicate ${ }^{*} \mathrm{u}>\mathrm{o}$ (e.g., כל). The manuscript consistently uses the short forms of the pronominal suffixes (e.g., $\Omega-, T^{-}$, etc.).

The following is a list of orthographical variants not subsumed under the above rules:

2:26 (col. 1, line 2) קרמות [ קרמת MT SP

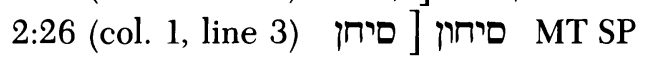

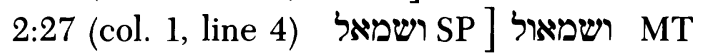

3:18 (col. 2, line 5) חלוצים [ חלצים

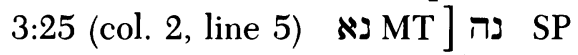

3:28 (col. 2, line 19) ינחל SP ] ינחיל MT SPmss. The context demands a hiphil verb. 4Q has not marked $*_{\overline{1}}$.

4:1 (col. 2, line 21) ועתה MT [ ועתה SP

The following is a list of morphological variants:

2:25 (col. 1, line 2) ישמעו MT ישמון SP

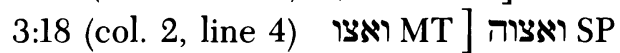

3:19 (col. 2, line 6) ומקניכם [ ומקנם MT. The Masoretes pointed the word as a plural; the consonantal text could be either singular or plural (without the mater lectionis yod). 4Q usually marks *ay > ê vowels with a mater lectionis, therefore we understand $4 \mathrm{Q}$ as a singular.

3:20 (col. 2, line 6) וירשו MT ] ויירשו SP. 4Q and MT have the perfect form of the verb, as does $\mathrm{G}$. SP has indicated the imperfect form.

3:21 (col. 2, line 6) הממלכות [ הממלכת MT SP. 4Q may be reading a singular noun, but since it is not consistent in its practice of marking accented $*_{\bar{a}}>\overline{0}$, we cannot be sure.

3:23 (col. 2, line 12) ואתחנן MT SP ] חואתחנה SPmss.

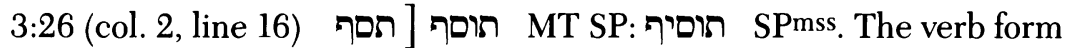
of $4 \mathrm{Q}$ may be a qal imperfect. $4 \mathrm{Q}$ would mark the vowel *aw > 0 in the hiphil of verbs I yod, since this is the original spelling. 4Q does mark *aw >ô in other examples (e.g., עוסף). יםף in the qal can function with an infinitive construct in the same way that a hiphil verb does, that is, meaning "to do again."7 Therefore, the texts of $4 \mathrm{Q}$ and MT and SP are equivalent in meaning.

4QDtd, as a Hasmonean manuscript and therefore relatively archaic (particularly in its orthographic practices), is fairly free of error (in fact, it contains no unique errors). It is thus difficult to place within a textual tradition. 

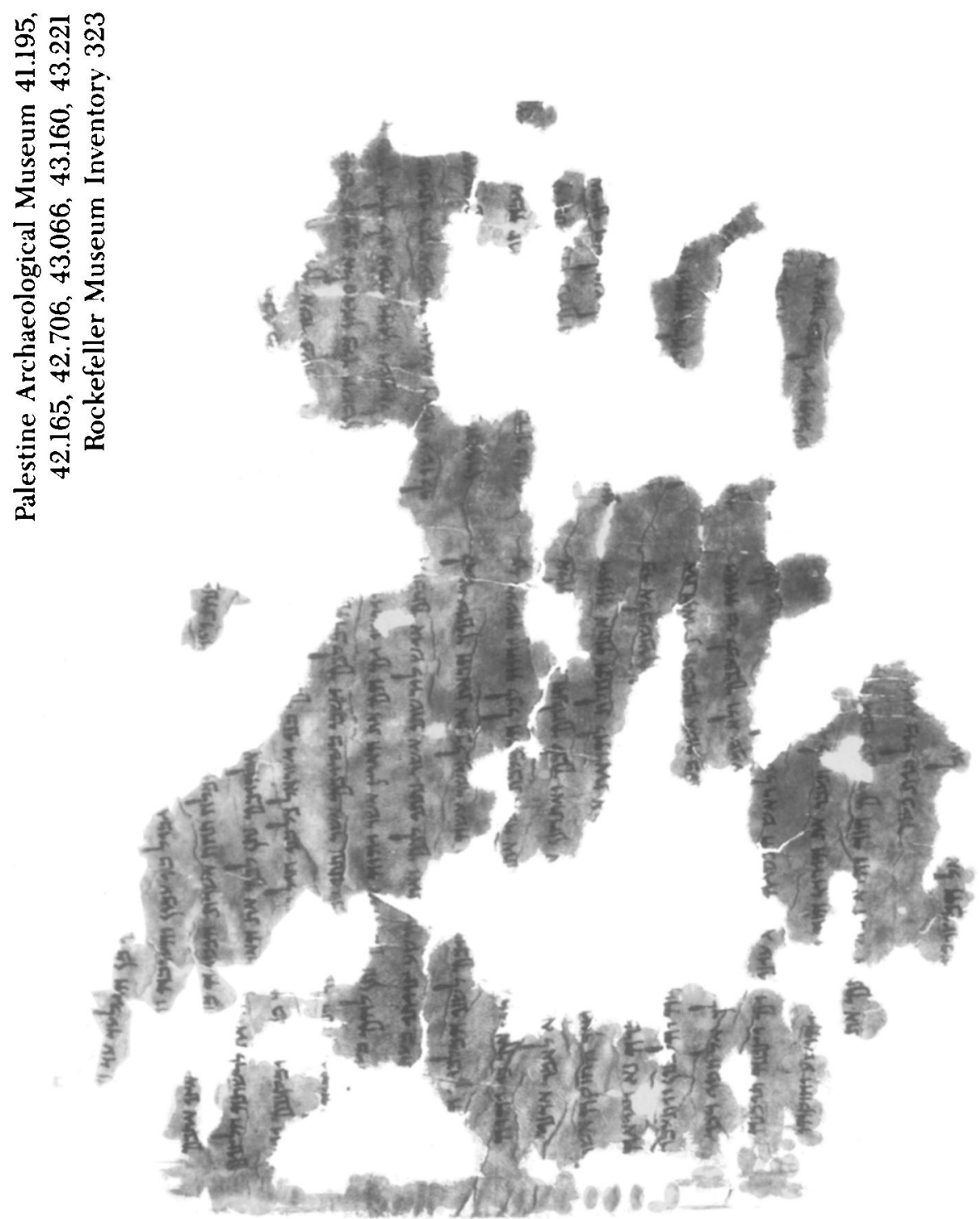
Where the manuscript does share error with the other witnesses, it appears to fall most frequently within the shared textual tradition of MT and SP. At 2:27 (line 4) and 2:31 (line 9) 4QDt ${ }^{\mathrm{d}}$ shares a scribal error with MT and SP against G. The error at 2:31, conflation, is not likely to have arisen independently and therefore may be cited as evidence that $4 \mathrm{QDt}$ f falls into the textual tradition of MT and SP. At 3:21 (line 10) 4Q agrees with MT and G against $\mathrm{SP}$ in assimilation to a common formula, an error that may have arisen independently in any of the witnesses. At 2:25 (line 10), 4Q agrees with SP against $\mathrm{MT}$ in the addition of the direct object marker, and at 3:19 (line 6), 4Q agrees with MT and $\mathrm{G}$ against $\mathrm{SP}$ in assimilation to a common word order. Again, either of these scribal errors could have arisen independently. These statistics do not leave us with a very clear picture of the textual tradition of $4 \mathrm{QDt}^{\mathrm{d}}$. We must simply say that $4 \mathrm{QDt}^{\mathrm{d}}$ is an ancient, good manuscript that preserves original readings in the majority of cases and preserves an archaic orthography.

\section{Column 1 Deut 2:24-36}

1 2 3 4

5

6 7 8 9 10 [32 10 11 [ 10

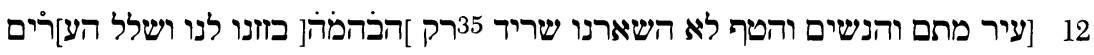

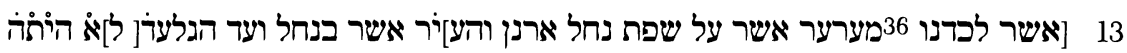

\section{Notes on Readings}

line Deut

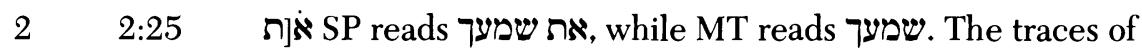
the letter cannot be šin, with a stroke coming down from the left, but this can be the downstroke of 'alep. The right arm of 'alep is also extant. Therefore we have restored את, in agreement with SP.

8 2:30 יה There are two traces of ink extant on the bottom of 
the fragment. Based on the amount of space available in the reconstructed text, we would read waw and he.

«i The crossbars of both he's are extant. A trace of ink is discernible to the left of the second he. Since the confusion of היא and aes not occur in this manuscript, and since היא is the correct pronoun, we have restored yod.

\section{Textual Notes}

\begin{tabular}{|c|c|c|}
\hline line & Deut & \\
\hline 2 & $2: 25$ & אי אית שמעך MT Tar (see note above). \\
\hline & $2: 27$ & $\begin{array}{l}\text { בד] MT SP Tar ] בדרך בדרד SPP G Vg: b'wrnn' 'wrnn' } \\
\text { Syr. We have a clear case of dittography in } 4 Q \text {, MT, et al. }\end{array}$ \\
\hline & $2: 27$ & אלך MT SP G Tar ] n'zl Syr. \\
\hline & $2: 27$ & לא MT SP G Tar Vg] wl' Syr. \\
\hline & $2: 27$ & אסור MT SP G Tar Vg ] nst?' Syr. \\
\hline & $2: 28$ & MT SP G Tar ] wnšt' Syr: et sic bibemus Vg. \\
\hline 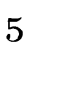 & $2: 28$ & 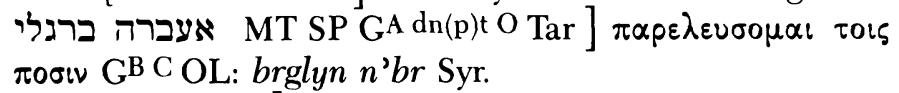 \\
\hline & $2: 29$ & לי MT SP G Tar ] ln Syr. \\
\hline & $2: 30$ & בו MT SP G ] btnnwmh Syr = בתחומיה Tar. \\
\hline & $2: 30$ & בידיך ] G Syr. \\
\hline 9 & $2: 31$ & לרשת ] GA B B C dn(p)t Syr. \\
\hline 10 & 2:33 & 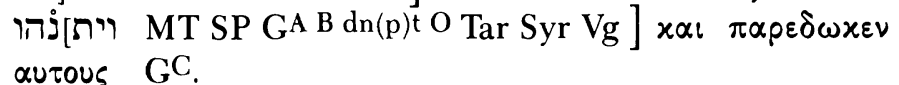 \\
\hline 0 & $2: 33$ & אלהינון MT SP G Tar Vg]> Syr. \\
\hline 10 & $2: 33$ & 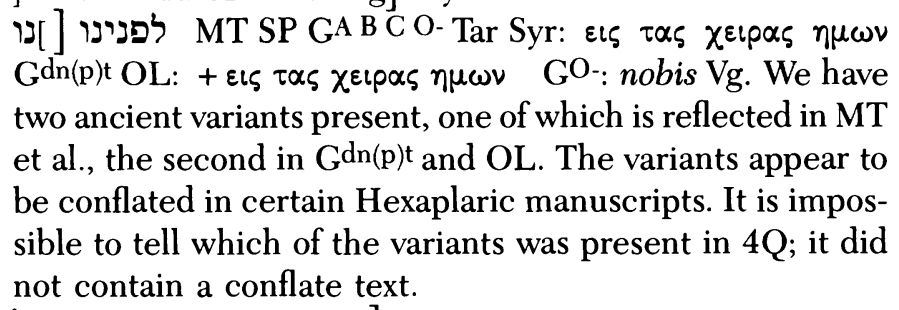 \\
\hline 11 & 2:34 & 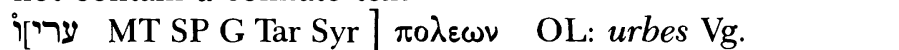 \\
\hline 11 & $2: 34$ & ההוא MT (see note above). \\
\hline 12 & $2: 35$ & 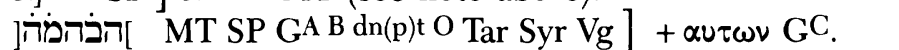 \\
\hline 13 & $2: 36$ & 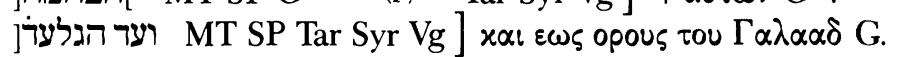 \\
\hline
\end{tabular}

\footnotetext{
${ }^{8} \mathrm{~A}$ case could also be made for haplography in $\mathrm{G}$ et al., but since the text is sensible without the second בדרך, on the principle of lectio brevior we prefer to view this as a dittography.
} 
Column 2 Deut 3:14-4:1

1 2

3 4

5 6 7

8

9

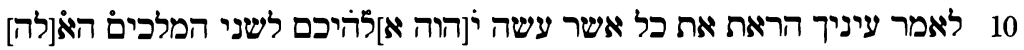
11

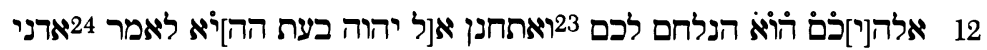

13 12

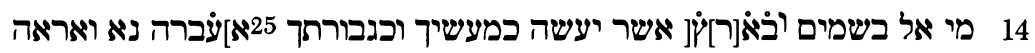

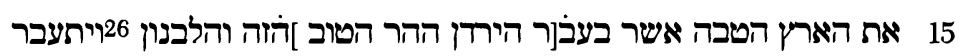

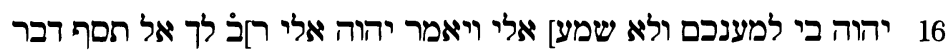

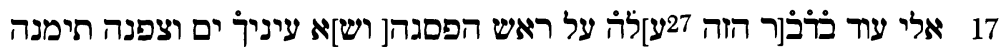

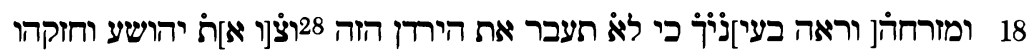

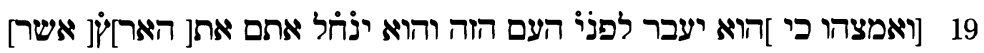

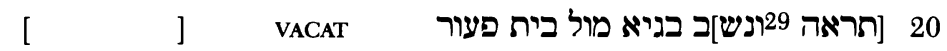

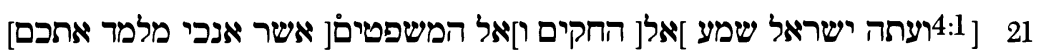

\section{Notes on Readings}

line Deut

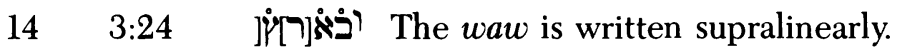

14 There is a spot of ink on the leather above the waw.

\section{Textual Notes}

line Deut

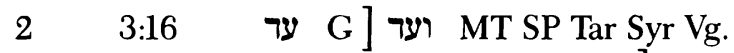

4 3:17 הפסגה MT SP G Tar Vg] wpsg' dbrmt' Syr.

4 אתכם MT SP GA C O Tar Syr Vg] is the result of inner Greek confusion of $\nu \mu \omega \nu$ and $\eta \mu \omega \nu$. This 
confusion happens throughout Deuteronomy and should not be taken as an indication of the original Hebrew text. ${ }^{9}$

\begin{tabular}{|c|c|c|}
\hline 5 & $3: 18$ & kol mzynyn 'ntwn Syr. \\
\hline 6 & 3:19 & 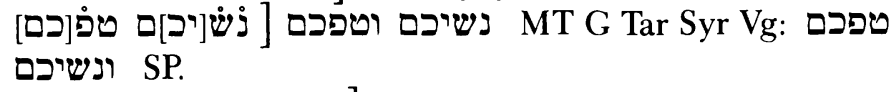 \\
\hline & $3: 19$ & MT SP G Tar ] + šbwqw Syr. \\
\hline & $3: 19$ & ידרעתْْْ MT SP G Tar Vg ] nd' 'n' gyr Syr. \\
\hline & 3:19 & 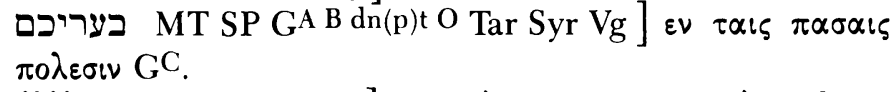 \\
\hline & 3:20 & 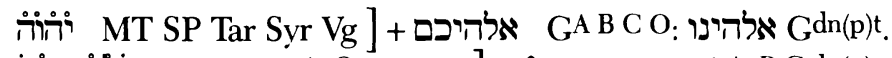 \\
\hline & $3: 20$ & 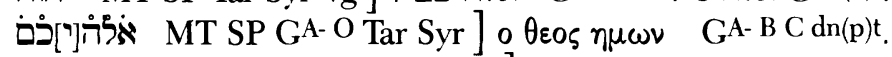 \\
\hline & $3: 20$ & להם MT SP GA C dn(p)t O Tar Vg ] $\eta \mu i \nu ~{ }^{B}$ : lkwn Syr. \\
\hline 10 & $3: 21$ & 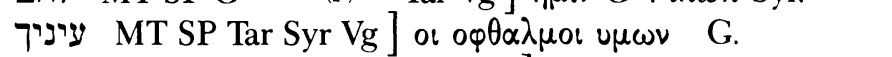 \\
\hline 10 & $3: 21$ & 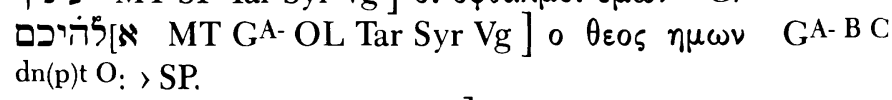 \\
\hline 11 & $3: 21$ & $\begin{array}{l}\text { יהוה MT SP GO- OL Tar Syr ] +o } \theta \varepsilon o \zeta \text { Gdn(p)t: to } \theta \varepsilon o \zeta \\
u \mu \omega \nu \text { GO-: +o } \theta \varepsilon 0 \varsigma \eta \mu \omega \nu \text { GA B C. }\end{array}$ \\
\hline 1 & $3: 21$ & MT SP G Tar Vg ] hlyn mlkwt’ Syr. \\
\hline 11 & $3: 21$ & MT SP G Tar Vg] gbryn 'ntwn Syr. \\
\hline 11 & $3: 22$ & 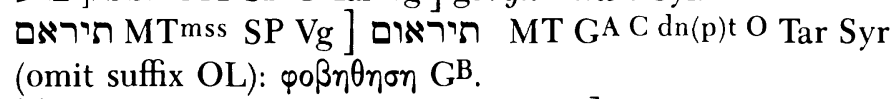 \\
\hline 2 & $3: 22$ & 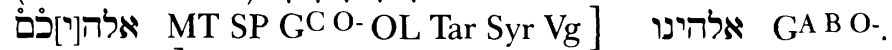 \\
\hline 2 & $3: 23$ & 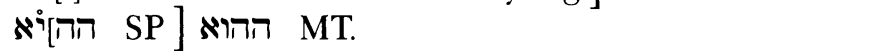 \\
\hline 2 & $3: 24$ & At the beginning of the verse, Syr adds $b b^{\prime} w$. \\
\hline 3 & $3: 24$ & 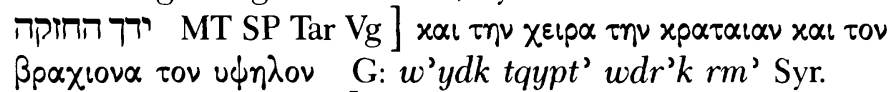 \\
\hline & $3: 25$ & 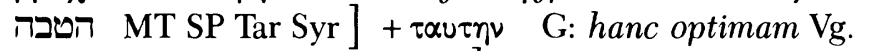 \\
\hline 5 & $3: 25$ & 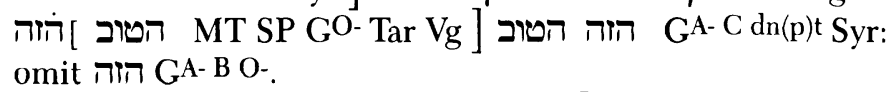 \\
\hline $16-17$ & $3: 26$ & 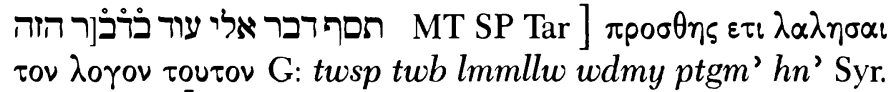 \\
\hline 7 & $3: 27$ & 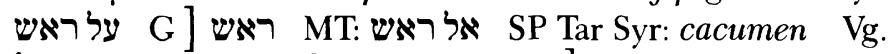 \\
\hline & $3: 27$ & 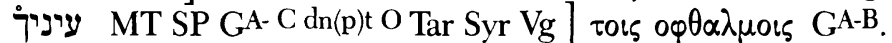 \\
\hline $17-18$ & $3: 27$ & 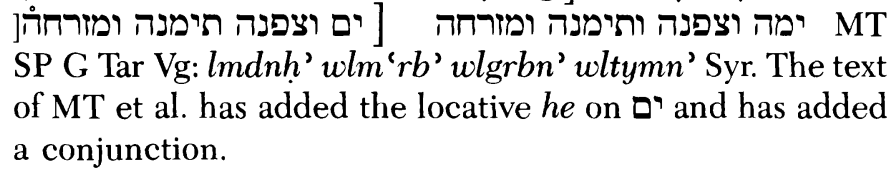 \\
\hline
\end{tabular}

\footnotetext{
${ }^{9}$ Joseph Ziegler, “Zur Septuaginta-Vorlage im Deuteronomium," ZAW 72 (1960) 245.
} 


\section{QDtg}

4 QDtg consists of eleven fragments, from four columns of text (the groupings are: fragment 1; fragments 2 and 3; fragments 4-9; fragments 10 and 11 ). The manuscript's original color was a yellowish brown; it is now faded to grayish brown in some places, stained a darker brown in others, and blackened in others. The surface of the leather was originally fairly smooth and matte. Fading has occurred in some places, and other places are so blackened that the letters are no longer visible. Some shrinkage and wrinkling have occurred, so that the leather becomes very thick in places. Some damage to the surface of the leather is visible. There are visible horizontal dry lines on the manuscript on fragment 3 . The average space from line to line is 7 millimeters. The column width in letter spaces is $52-67$, and in centimeters 12.5 (estimated). The number of lines per column was approximately 27 . There are three bottom margins present (frags. 1, 3, and 11), one top margin (frag. 4), two left margins (frags. 2 and 9), and one right margin (frag. 6).

The empty spaces in the manuscript correspond exactly to the petûhot and the setûmôt of MT: the empty spaces after 25:16 (reconstructed) and 25:19 (reconstructed) correspond to petûhôt in MT, and the empty spaces after 24:16 (reconstructed), 24:18 (reconstructed), 24:19, 24:20, 25:3 (reconstructed), and 25:4 (reconstructed) correspond to setûmôt in MT (after 24:19 there is only an unmarked space in $B H S$ ).

The fragments preserve portions of Deut 9:12-14; 23:18-20; 24:16-22; 25:1-5; 25:14-26:5; 28:21-24; 28:27-29.

The paleographical study of 4QDtg establishes its hand in the middle Herodian period, ca 1-25 CE. The letter size has become equal (see especially taw). Many letters are distinguished by keraiai or are thickened at the top (note particularly 'alep, gimel, zayin, tet, nun, 'ayin). Several features of the script mark it as Herodian: the base stroke of bet, which is penned from left to right, breaks through slightly at the corner of the downstroke; the crossbar of het projects to the right; yod is much shorter than waw, which is a decisive characteristic of later Herodian scripts (compare, for example, the yod and waw of 4QDt ${ }^{10}$ ); the head of final kaf loops into the downstroke at the right shoulder; and the usual form of medial mem is penned with the late Herodian technique, the left oblique being drawn upward to the right shoulder, then down into the downstroke and base. A tick is added on the left. Most significantly, on one letter this tick breaks through the left oblique (frag. 1, line 3).

The orthographic practice of 4QDtg never varies from that of the Masoretic Text. It uses matres lectionis to indicate *ay > ê (e.g., שניהם, frag. 2, line

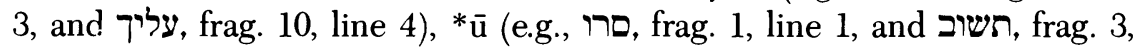

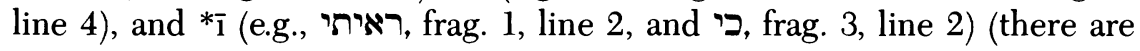

${ }^{10}$ White, "The All Souls Deuteronomy and the Decalogue," JBL 109 (1990) 193-206. 
no extant examples of *aw $>\hat{0})$. A mater lectionis is used to mark $* \bar{a}>\bar{o}$ when accented (e.g., ליתום אות ], frag. 3, line 1, and, 3, line 4), but not when unaccented (e.g., אנכי, frag. 3, line 3, and all forms of אלהים). לא לאים is consistently spelled defectively. However, זונה (frag. 2, line 2) is spelled with a waw in 4Q, as in MT and SP (this is inconsistent with the above-mentioned practice, but consistent with 4QDtg's constant agreement with MT; see below). The manuscript does not use matres lectionis to indicate any proto-Semitic short vowels, e.g., *a, *i, or *u. It uses the short forms for all pronominal suffixes and endings (e.g., T-, ת-, מהם).

There is one morphological variant in the tradition:

28:24 (frag. 10, line 4) השמידך [ השמדך SP. 4Q and MT are reading a niphal infinitive construct, while SP is reading a hiphil.

This manuscript stands squarely in the proto-rabbinic tradition in both orthography and text. 4Q never differs from MT in text or orthography (with one possible exception; see below at 23:20, line 4). Where there are disagreements among the other witnesses, when the reading of $4 \mathrm{Q}$ is clear, $4 \mathrm{Q}$ has the preferable text in all but three instances. In one case, it agrees with $\left.\mathrm{MT}, \mathrm{Gdn}^{\mathrm{dn}} \mathrm{p}\right) \mathrm{O}$ and SP against $\mathrm{GA} \mathrm{B} \mathrm{C}^{\mathrm{A}}$ an explicating plus $(25: 18$, line 4). At 28:29, line 3, it agrees with MT and the daughter versions in the addition of a prose particle. At 24:19, line 5, if $\mathrm{G}$ is original, then $4 \mathrm{Q}$ and MT, SP share an error. If $\mathrm{G}$ is an error, then $4 \mathrm{Q}$ does not share it. These statistics of shared error are certainly not definitive; however, there is no evidence to place 4QDtg in either the Old Greek or the Samaritan traditions. In addition, in its extant portions $4 \mathrm{Q}$ never disagrees with MT, consistently agreeing with it in all readings (of whatever type). Therefore, we believe $4 \mathrm{QDtg}$ is a member of the same textual family as MT.

Fragment 1 Deut 9:12-14

[ [הוצאת ממצרי]ם סרו[ מהר מן הדרך אשר צויתם עשו להם מסכה 13 ויואמר] 2

3

Bottom Margin

\section{Textual Notes}

line Deut

1 פ 1 MT SP GA B dn(p)t O Tar Vg ] $x \alpha \iota \pi \alpha p \varepsilon \beta \eta \sigma \alpha \nu \quad \mathrm{GC}^{\mathrm{C}}: s t w$ lhwn Syr.

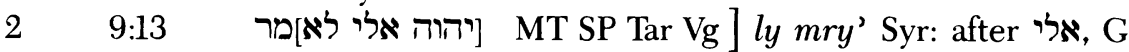

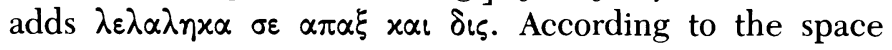


AQ Dt:
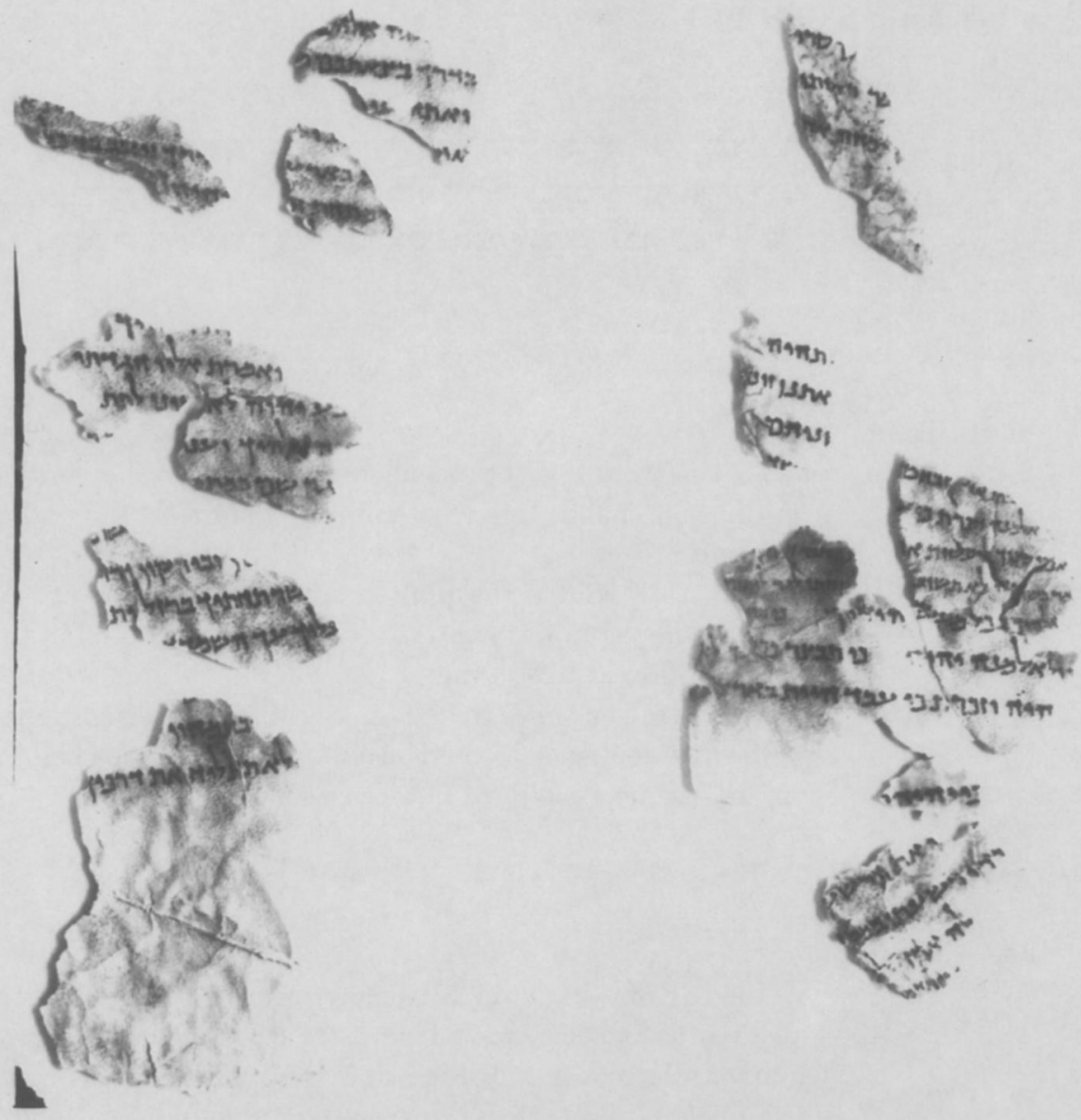

Palestine Archaeological Museum 42.001,

$42.636,42.713,42.732,43.063$

Rockefeller Museum Inventory 400 
Fragment 3 Deut 24:16-22

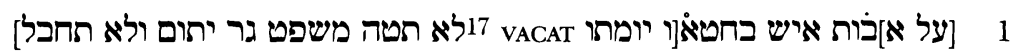
2 3

4 5 6 7

\section{Bottom Margin}

\section{Notes on Readings}

The leather of this fragment is split and shrunken; therefore some letters, while extant, are split in two or fragmentary.

\section{Textual Notes}

\begin{tabular}{|c|c|c|}
\hline line & Deut & \\
\hline 1 & 24:16 & איש MT SP G Tar ] $k l$ 'nš Syr. \\
\hline 3 & 24:18 & $\begin{array}{l}\text { אנכי מצוך לעשות MT SP G Tar Vg ] mpqd 'n'lkw'mr 'n'lk } \\
d t^{\prime} b d \text { Syr. }\end{array}$ \\
\hline 4 & 24:19 & 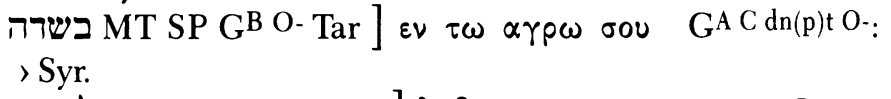 \\
\hline 4 & 24:19 & 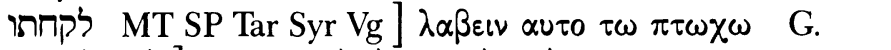 \\
\hline 4 & 24:19 & 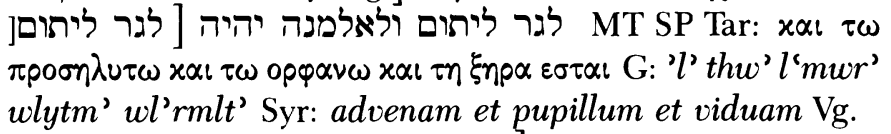 \\
\hline 5 & 24:19 & 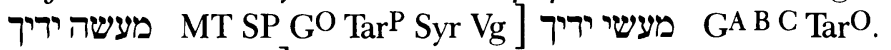 \\
\hline 5 & $24: 20$ & בי MT SP Tar Vg] וכי G Syr. \\
\hline 6 & 24:20 & 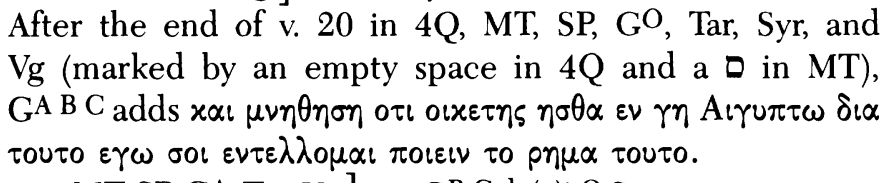 \\
\hline 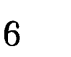 & 24:21 & בי MT SP GA- Tar Vg] וכי GB C dn(p)t O Syr. \\
\hline
\end{tabular}

Fragments 4 and $5 \quad$ Deut 25:1-5

\section{Top Margin}

25:1 2 
3 [ 4 5

\section{Textual Notes \\ line Deut

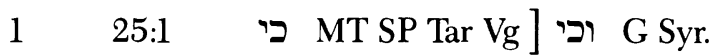

Fragments 6-9 Deut 25:14-26:5

1 2 3 4 5 6 ] $\quad$ vacat 8 9

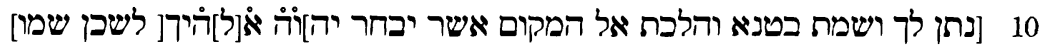

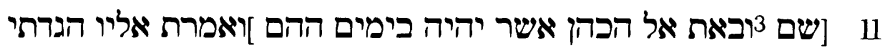

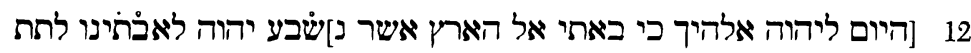

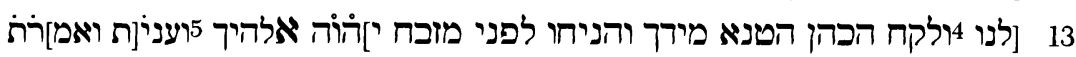

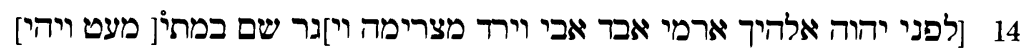

\section{Notes on Readings}

The top of fragment six is much damaged; the reading is certain, but the leather is split and shrunken so that the letters are split and at an angle.

line Deut

1 and 2 25:14-16 Since the photograph of frag. 6 presented in this article was taken, a new join has been made, reflected in the transcription of these lines.

26:4 The 'alep is extremely large and bold (and apparently made by a different hand), as if to conceal an error. 


\section{Textual Notes}

\begin{tabular}{|c|c|c|}
\hline line & Deut & \\
\hline 3 & 25:16 & MT SP G Tar ] hlyn wkl Syr. \\
\hline 3 & 25:17 & 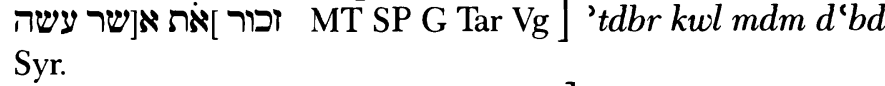 \\
\hline & 25:17 & 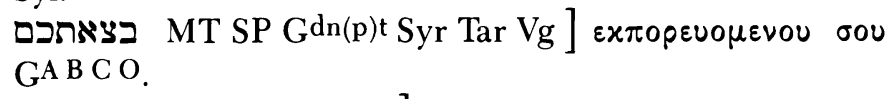 \\
\hline & 25:18 & MT SP G Tar Vg ] wqțlw bkwn Syr. \\
\hline 4 & 25:18 & כל MT SP Gdn(p)t O OL Tar Syr ] > GA B C Vg. \\
\hline 4 & 25:19 & 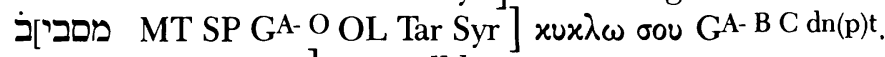 \\
\hline 12 & $26: 3$ & יהוה MT SP G Tar ] mry' 'lhk Syr. \\
\hline
\end{tabular}

Fragment $10 \quad$ Deut 28:21-24

1 2 3 4

\section{Textual Notes}

line Deut

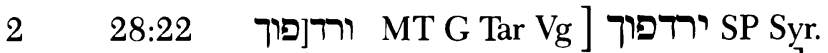

$428: 24$ עליך 28: MT SP GA C dn(p)t O Tar Syr Vg] > GB.

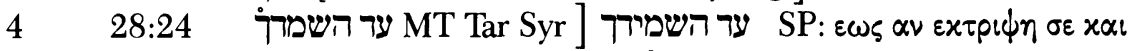

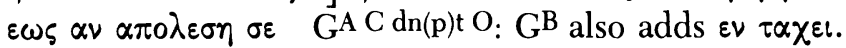

Fragment $11 \quad$ Deut 28:27-29

1 2 3

\section{Bottom Margin}

Notes on Readings

line Deut

1 28:27 ובעפלי[ט] 1 A portion of the base of final mem is extant. Based on the amount of space available to us, we can restore [בטחרי]ם (see below under "Textual Notes" for further commentary). 


\section{Textual Notes}

line Deut

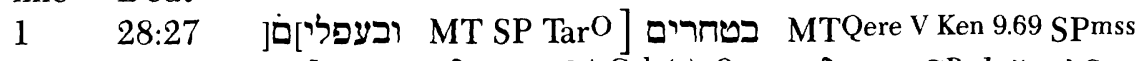

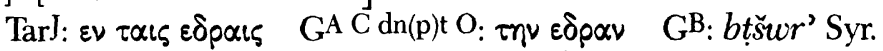
Our 4Q text could preserve either בעפרים or בטחסים. The $\mathrm{G}$ text could also be a translation of either word; it is also lacking waw. The Syriac text and $\mathrm{G}^{\mathrm{B}}$ preserve a singular noun. בעפרים ("hemorrhoids") must be original, and a change to a less offensive expression; therefore, we have restored בעפלים in 4Q.

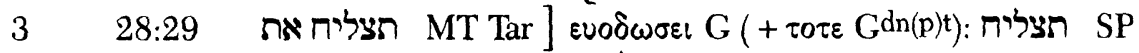
(Syr and Vg translate תצליח; it is not clear whether or not they contained $\Omega$ ).

32 דרכיך] $28: 29$ דרכך ST G Tar Vg: 'wrnnk lryš Syr. 